\title{
Postural physiotherapy for cervicogenic headache after occipital nerve block: a
}

\section{retrospective study}

\author{
Fisioterapia postural para a cefaleia cervicogênica após bloqueio do nervo occipital: um estudo \\ retrospectivo
}

Fisioterapia postural para la cefalea cervicogênica después del bloqueo del nervio occipital: un Estudio Retrospectivo

Alcântara Ramos de Assis César ORCID: https://orcid.org/0000-0002-7390-7282 Universidade Federal do Paraná, Brazil E-mail: alcantara.cesar@ufpr.br

Igor Dal Pozzo da Costa

ORCID: https://orcid.org/0000-0002-4647-5402 Universidade Federal do Paraná, Brazil E-mail: idalpozzo@me.com

Wesley Gabriel Novaes Botelho ORCID: https://orcid.org/0000-0001-7315-4201 Universidade Federal do Paraná, Brazil E-mail: wesleygabriel_dte@hotmail.com

Nicole Sperafico

ORCID: https://orcid.org/0000-0003-2277-2821 Faculdade São Leopoldo Mandic, Brazil E-mail: nicolesperafico@gmail.com

Anderson Dillmann Groto

ORCID: https://orcid.org/0000-0002-9028-4371 Universidade Federal do Paraná, Brazil E-mail: andersongr01@gmail.com

André Carvalho Felício

ORCID: https://orcid.org/0000-0003-4590-2983

Faculdade Ipemed de Ciências Médicas, Brazil Hospital Israelita Albert Einstein, Brazil E-mail: cf.andre@gmail.com

\begin{abstract}
Cervicogenic headache has a complex and poorly understood pathophysiology. Symptoms are typical and involve the C2 and C3 nerve roots. There are no specific recommendations for physical therapy, although occipital nerve block is a known pharmacological treatment. Some evidence suggests that hip rotation correction could aid in reducing cervical pain symptoms. The objective of this work is to evaluated the role of postural physiotherapy for hip rotation correction using the Maitland technique in patients with cervicogenic headache who underwent an occipital nerve block. In this retrospective, observational and uncontrolled study, patients were evaluated from January 2017 to February 2018. After diagnosis of cervicogenic headache they underwent anesthetic block, hip radiography with lower limb scanometry and cervical tomography, after which they were referred to physical therapy. The analog pain scale was used for evaluation at the time of diagnosis and after the proposed physiotherapy. Patients submitted to an occipital nerve block were divided into three groups: Group I ( $\mathrm{n}=15$, physical therapy with Maitland technique) had an analog pain score of 1.6 after the physical therapy, Group II ( $\mathrm{n}=11$, conventional physiotherapy) had an analog pain score of 3.7 after the physical therapy and Group III ( $n=13$, occipital nerve block only) had an analog pain score of 5.2 after the occipital nerve block. The results suggest that an occipital nerve block in combination with the Maitland technique is superior in patients with cervicogenic headache compared to nerve block only or blockade combined with non-specific physical therapy $(\mathrm{p}=0,013)$.
\end{abstract}

Keywords: Secondary headache; Physiotherapy; Nerve block.

\section{Resumo}

A cefaleia cervicogênica tem uma fisiopatologia complexa e mal compreendida. Os sintomas são típicos e envolvem as raízes nervosas C2 e C3. Embora o bloqueio do nervo occipital seja um tratamento farmacológico conhecido, não há recomendações específicas para fisioterapia. Algumas evidências sugerem que a correção da rotação do quadril ajuda a 
reduzir os sintomas de dor cervical. O objetivo deste trabalho é avaliar papel da fisioterapia postural na correção da rotação do quadril com a técnica de Maitland em pacientes com cefaleia cervicogênica submetidos ao bloqueio do nervo occipital. Neste estudo retrospectivo, observacional e não controlado, os pacientes foram avaliados de Janeiro de 2017 a Fevereiro de 2018. Após diagnóstico de cefaleia cervicogênica, foram submetidos a bloqueio anestésico e após radiografia do quadril com escanometria dos membros inferiores e tomografia cervical foram encaminhados para fisioterapia. A escala analógica de dor foi utilizada para avaliação no momento do diagnóstico e após a fisioterapia proposta. Pacientes submetidos a bloqueio do nervo occipital foram divididos em três grupos: Grupo I $(n=15$, fisioterapia com técnica de Maitland) apresentou média de 1,6 pontos na escala analógica de dor, Grupo II ( $\mathrm{n}=11$, fisioterapia convencional) apresentou média de 3,7 pontos na escala analógica de dor e o Grupo III ( $\mathrm{n}=13$, apenas bloqueio do nervo occipital) apresentou média de 5,2 pontos na escala analógica de dor. Os resultados sugerem que bloqueio do nervo occipital combinado com a técnica de Maitland é superior em pacientes com cefaleia cervicogênica comparado ao bloqueio apenas ou quando combinado com fisioterapia convencional $(\mathrm{p}=0,013)$.

Palavras-chave: Cefaleias secundárias; Fisioterapia; Bloqueio nervoso.

\section{Resumen}

La cefalea cervicogênica tiene una fisiopatología compleja y poco conocida. Los síntomas son típicos e involucran las raíces nerviosas $\mathrm{C} 2$ y C3. Aunque el bloqueo del nervio occipital es un tratamiento farmacológico conocido, no existen recomendaciones específicas para la fisioterapia. Alguna evidencia sugiere que corregir la rotación de la cadera ayuda a reducir los síntomas del dolor de cuello. El objetivo de este estudio es evaluar el papel de la fisioterapia postural en la corrección de la rotación de cadera mediante la técnica de Maitland en pacientes con cefalea cervicogênica sometidos a bloqueo del nervio occipital. En este estudio retrospectivo, observacional y no controlado, los pacientes fueron evaluados desde enero de 2017 hasta febrero de 2018. Luego del diagnóstico de cefalea cervicogênica, fueron sometidos a bloqueo anestésico y después de una radiografía de cadera con escanometria de miembros inferiores y tomografía cervical fueron referidos para fisioterapia. La escala de dolor analógica se utilizó para la evaluación al diagnóstico y después de la fisioterapia propuesta. Los pacientes sometidos a bloqueo del nervio occipital se dividieron en tres grupos: el grupo I ( $n=15$, fisioterapia con la técnica de Maitland) tenía una media de 1,6 puntos en la escala analógica de dolor. El grupo II ( $n=11$, fisioterapia convencional) tenía una media de 3,7 puntos en la escala analógica del dolor y el Grupo III ( $n=13$, bloqueo del nervio occipital solamente) tuvo una media de 5,2 puntos en la escala analógica del dolor. Los resultados sugieren que el bloqueo del nervio occipital combinado con la técnica de Maitland es superior en pacientes con cefalea cervicogênica en comparación con el bloqueo solo o cuando se combina con fisioterapia convencional $(\mathrm{p}=$ $0,013)$.

Palabras clave: Cefaleas secundarias; Fisioterapia; Bloqueo nervioso.

\section{Introduction}

Cervicogenic headaches are not yet included in the current classification (version XX) of the lnternational Headache Society (Correia \& Monteiro, 1992) as a specific and isolated category. They are included in a broad group of headaches associated with neck problems because the characteristics of this type of headache are different from those of migraine and tension headache (Correia \& Monteiro, 1992). The fact that some headaches are triggered by neck dysfunction has been known for a long time (Pfaffenrath, 1989; Bartschi-Rochaix, 1968).

Cervicogenic headaches are usually unilateral severe pain attacks that sometimes slightly spread from the midline, although they are always more pronounced on the original side. The age of the affected individuals varies between 25 and 59 years and females are more frequently affected. Most patients experience a constant headache with episodes of severe attacks. The duration of the attacks is typically one to three days but may range from hours to one week (Barmherzig \& Kingston, 2019; Gallagher, 2007; Blumenfeld \& Siavoshi, 2018; Xiao et al, 2019; Antonaci \& Inan, 2021).

Some reports suggest a role of cervical structures, such as vertebrae, intervertebral discs, uncovertebral joints, vertebral arteries, and cervical roots as headache triggers (Fredriksen, Hovdal \& Sjaastad, 1987; Becker, 2010). Other studies correlate the occipital nerve with cervicogenic headache because of the convergence of cervical nociceptive inputs with the trigeminal nucleus caudalis and sensitization of the trigeminal vascular system (International Headache Society, 2013).

Cervicogenic headache typically starts in the occipital region and radiates to the orbito-fronto-temporal or facial region where pain intensity is greater. There is no tendency for nocturnal occurrence. The pain is usually shock-like, eventually throbbing, and patients describe it as strong or very strong, often debilitating, and tending to become chronic. Physical 
examination shows rigidity and a restricted cervical range of passive motion. Hypoesthesia can occur in the areas innervated by the $\mathrm{C} 2$ and $\mathrm{C} 3$ nerves.

Pharmacological treatments usually include muscle relaxants (tizanidine and cyclobenzaprine), antidepressants (venlafaxine, duloxetine, nortriptyline, and amitriptyline), and neuromodulators (pregabalin, gabapentin, and topiramate). Anesthetic blockade, combined or not with a corticosteroid or botulinum toxin injection are also used (Wang \& Wang, 2014; Karadas et al, 2012). Moreover, non-pharmacological resources may be useful auxiliary tools in the treatment of cervicogenic headaches (Côté et al, 2019; Peñas et al, 2020), in particular, physiotherapy, acupuncture, and shiatsu (Sakata \& Issy, 2010; Dach et al, 2015).

Osteopathy, a commonly used physiotherapy technique, is a manual treatment method developed in the United States in the late 19th century by the physician Andrew Taylor Still (Dach et al, 2015). One of the objectives of this therapy is to recover physiological movement in areas where movement is restricted or in areas that are dysfunctional. The primary targets of osteopathy are soft tissues, skin, muscles, ligaments and fascias, vertebrae, and joints. The main goals of the technique are stretching and elimination of retractions, spasms, and painful muscle knots, thereby normalizing the osteoarticular system through manipulation (Thrust Technique) (Le Corre \& Rageot, 2004; Rachid \& Pinheiro, 2009).

In this study, the osteopathic method Maitland technique was used. It consists of joint micromovements performed in a slow and oscillatory manner (Sociedade Brasileira para Estudo da Dor, 2017; Carvalho, 2019). The concept is based on the active, passive, and accessory movement of musculoskeletal groups using manual techniques (mobilizations and manipulations) to reestablish their normal function.

The objective of the present study was to assess whether a physiotherapy protocol focusing on the neuroaxis through hip correction (Maitland Technique) would be a useful adjuvant measure in alleviating pain in patients with cervicogenic headache subjected to the standard treatment (infiltration anesthesia of the occipital nerve). Our a priori hypothesis was that the Maitland technique associated with occipital nerve infiltration is superior to the standard treatment with or without conventional physiotherapy (thrust technique).

\section{Methodology}

\section{Location}

This was a retrospective, observational, uncontrolled case series study conducted with patients with suspected diagnosis of cervicogenic headache at the Hospital 10 de Julho in the city of Pindamonhangaba, São Paulo, between January 2017 and February 2018. The study was approved by the hospital ethics committee. The work of Pereira et al (2018) was used as a methodological basis.

\section{Procedures}

The diagnosis of cervicogenic headache was made based on patients' complaints and findings after clinical, neurological, and cephalic examination (e.g. cervical headache that is unilateral, caused by a trigger point, radiating to the frontotemporal region, shock/burning type of pain and very intense, pain triggered upon cervical pressure). After the diagnosis was confirmed and in the absence of red flags (Sociedade Brasileira para Estudo da Dor, 2017) an unilateral anesthetic block of the occipital nerve was performed using $1 \mathrm{~mL}$ of dexamethasone at a concentration of $2 \mathrm{mg}$ and $2 \mathrm{~mL}$ of lidocaine at $1 \%$ without a vasoconstrictor (a total of $3 \mathrm{~mL}$ was infused).

After the blockade was performed, the patients underwent examinations requested as part of a protocol at the Hospital 10 de Julho. These included panoramic X-ray of the hip, scanometry of the lower extremities and cervical tomography (C1 
through C7). The aim of these examinations was to identify hip misalignment and rule out secondary causes of cervicogenic headache.

After the examinations, the patients were assigned to conventional physiotherapy (Thrust technique) (Group II) or postural physiotherapy (Maitland technique) (Group I) based on professional preference. All patients, regardless of the used technique, underwent eight sessions, twice a week for 30 days.

\section{Inclusion criteria and outcome}

Inclusion criteria: Patients with suspected diagnosis of cervicogenic headache with a score of 10 in the analog pain scale, subjected to occipital nerve block and reassessed 30 days after the procedure.

Exclusion criteria: Patients with suspected diagnosis of cervicogenic headache with a score of less than 10 in the analog pain scale, who therefore did not undergo an occipital nerve block (the block was only performed on patients with acute cervicogenic headache, i.e., a pain score of 10); patients with a score of 10 in the analog pain scale and who were subjected to occipital nerve block but with loss of the segment; patients with spine and hip musculoskeletal disorders, previously subjected or not to surgery and treatments that could hinder or contraindicate physiotherapy; other headaches that did not meet the inclusion criteria.

The outcome measure used to assess these patients was the analog pain scale at the time of diagnosis and after anesthetic blockade with or without the use of the proposed physiotherapy techniques.

\section{Statistical analyses}

The patients were divided into three groups. Group I: patients who underwent anesthetic block followed by the Maitland technique; Group II: patients who underwent the anesthetic block followed by the standard physiotherapy technique (Thrust); and Group III: patients who underwent the anesthetic block without physiotherapy. The analysis of the results was performed using the Welch method of ANOVA in the Minitab software.

\section{Results and Discussion}

Most patients in our study were women. The age ranged between 17 and 73 years. The patients were divided according to treatment modality: patients who underwent the proposed physiotherapy (15), patients who underwent conventional physiotherapy (11), and patients who did not undergo physiotherapy (13). The mean age of each group is described in Figure 1. The nerve roots $\mathrm{C} 2$ and $\mathrm{C} 3$ of these patients were affected, with a mean difference in leg length of $0.485 \mathrm{~cm}$ in the right leg. There were no patients with changes in the pelvis or with other complications. One patient did not respond to the occipital block. Two patients were subjected to a bilateral cervical block and one patient underwent the occipital nerve block in another center. 
Figure 1: Mean age of participants by group.

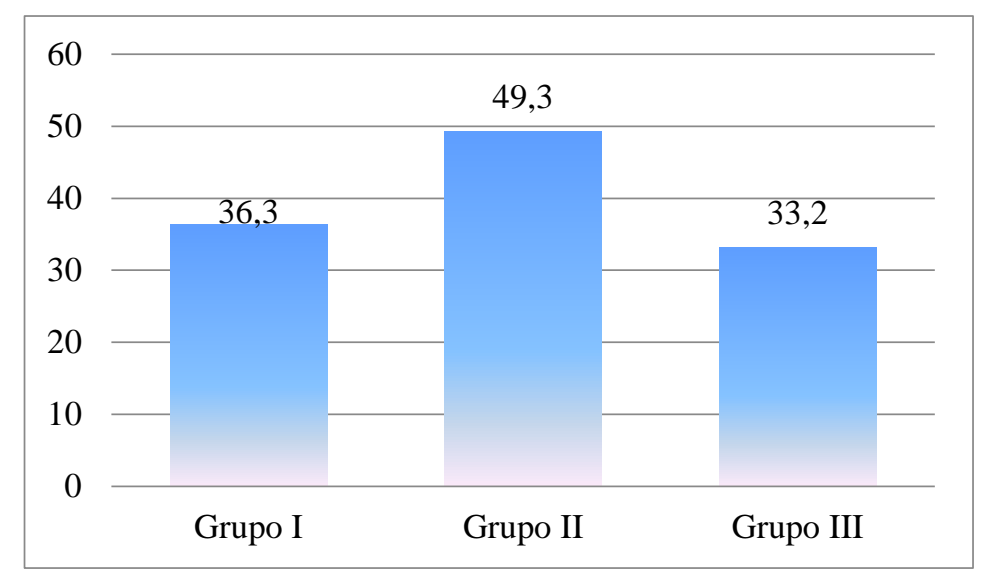

Source: Authors (2021).

Group I: Patients who underwent the proposed physiotherapy

The sample included 15 patients, of which three were men and 12 were women. The mean age was 36.3 years. The initial pain score (before block) in the analog pain scale was 10. The mean pain score after block and proposed physiotherapy was 1.6 on the analog scale (Figure 1 and 2).

\section{Group II - Patients who underwent conventional physiotherapy}

In total, 11 patients were subjected to an occipital nerve block and to non-specified physiotherapy. Ten of these patients were female and one was male. The mean age was 49.3 years. The initial pain score (before block) on the analog pain scale was 10. The mean pain score after block and unspecified physiotherapy was 3.7 on the analog scale (Figure 1 and 2).

Group III - Patients who underwent occipital nerve block without physiotherapy

A total of 13 patients, of which five were male and eight were female, underwent an occipital nerve block without physiotherapy. The mean age was 33.2 years. The initial pain score (before block) on the analog pain scale was 10 . The mean pain score after block was 5.2 on the analog pain scale (Figure 1 and 2). 
Figure 2: Mean analog pain scale after occipital nerve block by group.

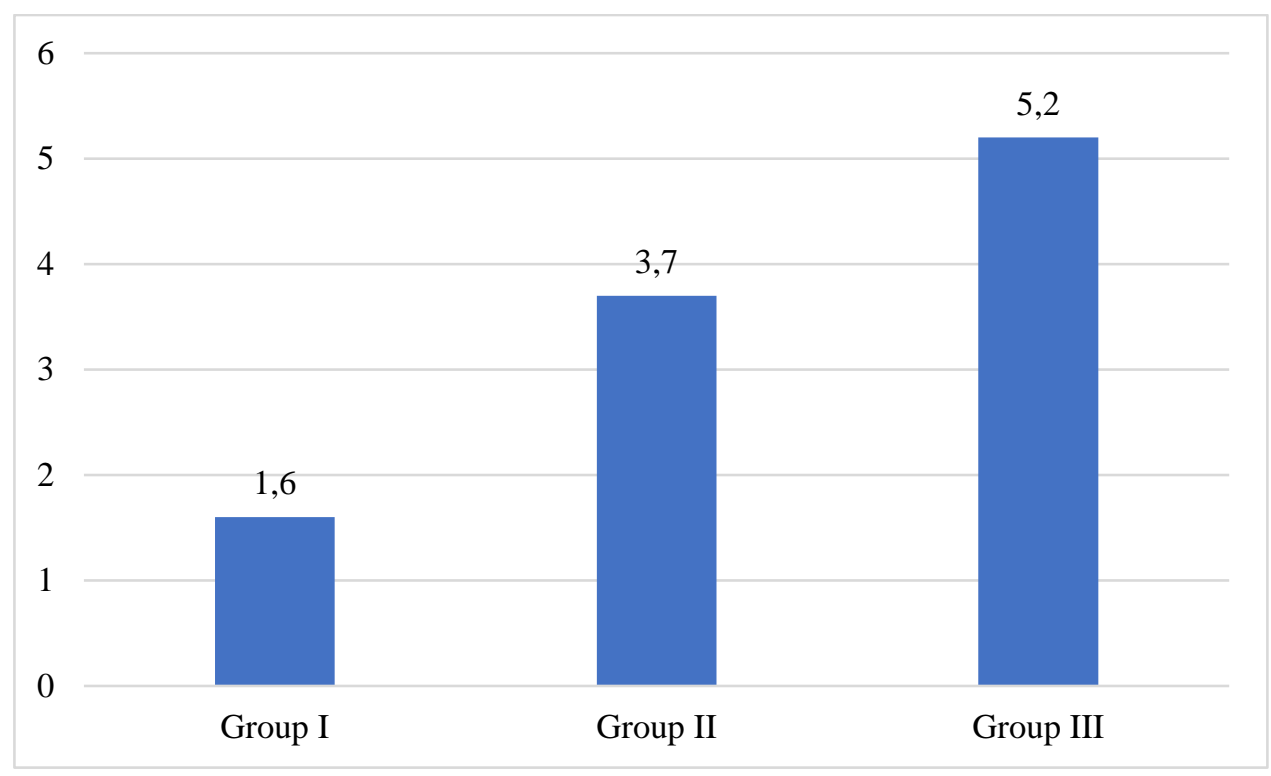

Source: Authors (2021).

Figure 2 shows the mean level of pain of participants in groups I, II and III. By performing the statistical tests, it was observed that the level of pain in participants in Group I differed from the level of pain in participants in Group II and Group III $(\mathrm{p}=0.013)$. Thus, participants who underwent occipital nerve block and underwent physical therapy with the Maitland technique (Group I) had lower levels of pain than those who underwent occipital nerve block and underwent conventional physical therapy (Group II) and those who underwent only occipital nerve block (Group III). There was no statistically significant difference between the pain levels of participants in Group II and Group III ( $p>0.05)$.

The relevance of cervicogenic headaches among the already classified headaches does not arise from their prevalence but from a clear interest that has been demonstrated through attempts to describe them since 1853. However, a detailed search for references on this topic showed that this type of headache is no longer of interest to specialists in the field, indicated by the low number of recent publications on this topic.

During the search for publications on the subject, the importance of occipital nerve block in the treatment of several types of headache became evident, probably because of the convergence of cervical nociceptive inputs with the trigeminal nucleus caudalis, involved in the pathophysiology of pain in other types of headaches. The block solution was composed of a combination of a corticosteroid with an anesthetic (immediate action). A volume adequate for the specific region was locally infiltrated with post-pressure dispersion and local massage, in addition to the washout effect.

In this study, the most affected nerve roots of the cervical region were $\mathrm{C} 2$ and $\mathrm{C} 3$, which is in concordance with the results of previous studies. However, the nerve roots $\mathrm{C} 5$ and $\mathrm{C} 7$ were also affected in some cases.

Even if the current study has a weak level of evidence, it demonstrated the importance of continued treatment after nerve block and correlated this type of headache with neuroaxis disorders as a cause of this ailment.

To establish this association, we adopted an assessment procedure that had as fixed points the inclusion and exclusion criteria and, most importantly, selected only patients with the maximum pain score as the starting point for treatment evaluation. Although other available scales are less prone to biases, it was not possible to use them in this study because it was an uncontrolled study conducted in a setting that did not allow a prospective study design with stronger statistical tools. Thus, the ethics committee of the center allowed the retrospective collection of data which led to changes in the initially planned methodology and resulted in a new and biased approach. 
To demonstrate the change in hip rotation, scanometry of the legs (full length) was performed because it is less costly than tomography (single film, which minimizes measurement bias). Scanometry revealed leg-length discrepancy and is crucial to demonstrate that relationship with regard to hip rotation, neuroaxis change, and as the probable cause of cervicogenic headache not caused by trauma (excluded through anamnesis and cervical CT), as shown by the results of this study. The hip X-ray aimed at showing hip abnormalities that may skew the result. No patient in the present study showed signs of hip abnormalities.

Using a systematic evaluation according to the inclusion and exclusion criteria with the aim of demonstrating this correlation, we demonstrated the potential effectiveness of the adopted therapy using the Maitland physiotherapy technique (depth testing, sacrotuberous ligament testing, spring testing, anterior and posterior iliac rotation testing) by comparing the used techniques.

The presented data show that the cervicogenic headache almost ceased to exist after correcting the difference between the legs. Moreover, the patients that were followed as outpatients after the end of this study were free of acute pain crises for months after the described procedure. Even the patients with extreme differences between the legs and who received insoles to correct the length discrepancy were free of pain crises.

To further neuroaxis correction, even in the absence of pain crises, some patients (the group who was subjected to the indicated technique) continued to undergo physiotherapy with complementary techniques (global postural re-education and Pilates) and have remained free of pain crises and additionally showed improvement of other neuroaxis problems.

\section{Conclusion}

The results of the present study allow inferring the possibility of correlating cervicogenic headaches with neuroaxis disorders, for example hip rotation. We therefore suggest that further prospective studies with optimized statistical tools, better class and level of evidence, and with control groups to demonstrate the relationship between cervicogenic headaches and neuroaxis disorders based on the presented diagnostic hypothesis.

\section{References}

Antonaci, F., \& Inan, L. E. (2021). Headache and neck. Cephalalgia, 41(4), 438-442. https://doi.org/10.1177/0333102420944878

Barmherzig, R., \& Kingston, W. (2019). Occipital Neuralgia and Cervicogenic Headache: Diagnosis and Management. Current Neurology and Neuroscience Reports, 19(5), 20. https://doi.org/10.1007/s11910-019-0937-8

Bartschi-Rochaix, W. (1968). Headaches of cervical origin. In Handbook of Clinical Neurology. Vol. 5 Headache and cranial neuralgia (pp. 192-203). North Holland Publishing Company.

Becker, W. J. (2010). Cervicogenic Headache: Evidence That the Neck is a Pain Generator. Headache: The Journal of Head and Face Pain, 50(4), 699-705. https://doi.org/10.1111/j.1526-4610.2010.01648.x

Blumenfeld, A., \& Siavoshi, S. (2018). The Challenges of Cervicogenic Headache. Current Pain and Headache Reports, 22(7), 47. https://doi.org/10.1007/s11916-018-0699-z

Carvalho, D. de S. (2019). Síndrome da Cefaléia Cervicogênica. Revista Neurociências, 9(2), 57-59. https://doi.org/10.34024/rnc.2001.v9.8920

Correia, C., \& Monteiro, P. (1992). Cefaleia Cervicogênica. Acta Médica Portuguesa, 5(3), 155-158.

Côté, P., Yu, H., Shearer, H. M., Randhawa, K., Wong, J. J., Mior, S., Ameis, A., Carroll, L. J., Nordin, M., Varatharajan, S., Sutton, D., Southerst, D., Jacobs, C., Stupar, M., Taylor-Vaisey, A., Gross, D. P., Brison, R. J., Paulden, M., Ammendolia, C., \& Lacerte, M. (2019). Non-pharmacological management of persistent headaches associated with neck pain: A clinical practice guideline from the Ontario protocol for traffic injury management (OPTIMa) collaboration. European Journal of Pain, 23(6), 1051-1070. https://doi.org/10.1002/ejp.1374

Dach, F., Éckeli, Á. L., Ferreira, K. dos S., \& Speciali, J. G. (2015). Nerve Block for the Treatment of Headaches and Cranial Neuralgias - A Practical Approach. Headache: The Journal of Head and Face Pain, 55, 59-71. https://doi.org/10.1111/head.12516

Fredriksen, T. A., Hovdal, H., \& Sjaastad, O. (1987). "Cervicogenic Headache”: Clinical Manifestation. Cephalalgia, 7(2), 147-160. https://doi.org/10.1046/j.1468-2982.1987.0702147.x

Gallagher, R. M. (2007). Cervicogenic headache. Expert Review of Neurotherapeutics, 7(10), 1279-1283. https://doi.org/10.1586/14737175.7.10.1279 
Research, Society and Development, v. 10, n. 12, e165101219994, 2021

(CC BY 4.0) | ISSN 2525-3409 | DOI: http://dx.doi.org/10.33448/rsd-v10i12.19994

Internation Headache Society. (2013). International Classification of Headache Disorders.

Karadas, O., Ozturk, B., Ulas, U. H., Kutukcu, Y., \& Odabasi, Z. (2012). The Efficacy of Botulinum Toxin in Patients with Cervicogenic Headache: a PlaceboControlled Clinical Trial. Balkan Medical Journal, 29(2), 184-187. https://doi.org/10.5152/balkanmedj.2012.003

Le Corre, F., \& Rageot, E. (2004). Atlas Prático de Osteopatia. Artmed.

Peñas, C. F. de las, Florencio, L. L., Plaza-Manzano, G., \& Arias-Buría, J. L. (2020). Clinical Reasoning Behind Non-Pharmacological Interventions for the Management of Headaches: A Narrative Literature Review. International Journal of Environmental Research and Public Health, 17(11), 4126. https://doi.org/10.3390/ijerph17114126

Pereira, A. S., et al. (2018). Metodologia da pesquisa cientifica. [free e-book]. Santa Maria: UAB/NTE/ UFSM. https://repositorio.ufsm.br/bitstream/handle/1/15824/Lic_Computacao_Metodologia-Pesquisa-Cientifica.pdf?sequence=1

Pfaffenrath, V. (1989). Cervicogenic headache and its differential diagnosis. In Migraine and Other Headaches (pp. 161-177). Parthenon.

Rachid, R., \& Pinheiro, L. T. M. (2009). A terapia osteopática manipulativa na cefaleia cervicogênica. Revista Brasileira de Promoção Da Saúde, 22(2), 128134.

Sakata, R. K., \& Issy, A. M. (2010). Bloqueios para tratamento da dor. Manole.

Sociedade Brasileira para Estudo da Dor. (2017). Cefaleia Cervicogênica.

Xiao, H., Peng, B., Ma, K., Huang, D., Liu, X., Lu, Y., Liu, Q., Lu, L., Liu, J., Li, Y., Song, T., Tao, W., Shen, W., Yang, X., Wang, L., Zhang, X., Zhuang, Z., Liu, H., \& Liu, Y. (2019). The Chinese Association for the Study of Pain (CASP): Expert Consensus on the Cervicogenic Headache. Pain Research and Management, 2019, 1-6. https://doi.org/10.1155/2019/9617280

Wang, E., \& Wang, D. (2014). Treatment of Cervicogenic Headache with Cervical Epidural Steroid Injection. Current Pain and Headache Reports, 18(9), 442. https://doi.org/10.1007/s11916-014-0442-3 